\title{
International Committee on Systematic Bacteriology Subcommittee on the Taxonomy of Agrobacterium and Rhizobium
}

\begin{abstract}
Minutes of the Meeting, 10 December 1992, Cancun, Mexico
Minute 1. Call to order. An open meeting was called to order by J. P. W. Young at 1500 on 10 December 1992 in the Hotel Fiesta Americana Condesa, Cancun, Mexico, during the 9th International Congress on Nitrogen Fixation.

Minute 2. Record of attendance. The members present were Y. M. Barnet, J. E. Cooper, K. Lindstrom, M. E. Martinez-Romero, and J. P. W. Young. Also present as invited guests were B. Dreyfus, B. Eardly, D. Prevost, and P. van Berkum. Apologies were received from P. H. Graham (Chairman), M. Gillis, and B. D. W. Jarvis (Secretary).

Minute 3. Species names. Bacterial species names should refer to groups of genetically related bacteria that are distinguishable from other groups. Bacterial taxonomy has to be based on chromosomally encoded characteristics of the strains. Guidelines for the proposal of new species have been published (Graham et al., Int. J. Syst. Bacteriol. 41:581-587, 1991). Valuable approaches to strain classification can be based on analyses of sequences from ribosomal genes and on levels of total DNA homology.

Minute 4. New Rhizobium species. The subcommittee has reviewed the evidence that supports newly proposed species and recommends the acceptance of the following three species: Rhizobium huakuii (nodulating Astragalus sinicus and phylogenetically related to Rhizobium loti); Rhizobium tropici (broad host range, nodulating Phaseolus vulgaris); and Rhizobium etli (nodulating $P$. vulgaris).

Minute 5. Bean rhizobia. The subspecies status of $R$. tropici strains should be reviewed in the future, as should the existence of biovars of $R$. etli. The name Rhizobium leguminosarum biovar phaseoli should be used only for strains that are closely related in their chromosomal genes to the other biovars of this species (for example, strain JI8002). Commonly used strain CFN 42 and its derivative, strain

Esperanza Martinez (Centro de Investigación sobre Fijación de Nitrógeno, Cuernavaca Mor., Mexico.) has agreed to identify small numbers of such strains as a service to the international community.

Minute 6. Sinorhizobium. The subcommittee does not endorse the proposed genus Sinorhizobium, but recommends that Rhizobium fredii be retained, as fast-growing soybean nodulating rhizobia are closely related to other species in the genus Rhizobium.

Minute 7. Bradyrhizobium. After discussion it was decided that Bradyrhizobium species identification should be reconsidered at a future date since a large number of species remain to be described, especially among the leguminous tree rhizobia.

Minute 8. Reference strains. The subcommittee has prepared a list of reference strains that is available to interested people, who may request it from Brion Jarvis (Department of Microbiology and Genetics, Massey University, Palmerston North, New Zealand). The U.S. Department of Agriculture Rhizobium culture collection (Peter van Berkum, Soybean and Alfalfa Research Laboratory, U.S. Department of Agriculture Agricultural Research Service, West Beltsville, Md.) has agreed to keep and deliver upon request these Rhizobium and Bradyrhizobium reference strains.

Minute 9. Present membership. The present membership of the subcommittee is as follows: P. H. Graham (Chairman), United States; B. D. W. Jarvis (Secretary), New Zealand; Y. M. Barnet, Australia; R. S. Bradley, Costa Rica; J. E. Cooper, United Kingdom; M. Gillis, Belgium; K. Lindstrom, Finland; M. E. Martinez-Romero, Mexico; and J. P. W. Young, United Kingdom.

Minute 10. Adjournment. The meeting was adjourned at 1700 on 10 December 1992.
\end{abstract} CE3, belong to $R$. etli. CIAT 899 and CFN 299 are strains of $R$. tropici. Strains from Phaseolus sp. should be referred to as Rhizobium sp. (Phaseolus) if their species is uncertain.
M. E. Martinez-Romero, Minutes Secretary B. D. W. Jarvis, Secretary 